\title{
Long-term effect of inorganic fertilizers and amendments on productivity and root dynamics under maize-wheat intensive cropping in an acid Alfisol
}

\author{
Shweta Shambhavi ${ }^{1}$, Rakesh Kumar ${ }^{2 *}$, S. P. Sharma ${ }^{3}$, Gayatri Verma ${ }^{4}$, R. P. Sharma ${ }^{3}$ and \\ Sanjay K. Sharma ${ }^{3}$ \\ ${ }^{1}$ Department of Soil Science and Agricultural Chemistry, Bihar Agriculture University (BAU), Sabour (Bihar), \\ INDIA \\ ${ }^{2}$ Department of Soil Science and Agricultural Chemistry, BAU, Sabour (Bihar), INDIA \\ ${ }^{3}$ Department of Soil Science, Chaudhary Sarwan Kumar Himachal Pradesh Agricultural University, Palampur- \\ 176062 (Himachal Pradesh), INDIA \\ ${ }^{4}$ Department of Soil Science, Punjab Agricultural University, Gurdaspur (Punjab), INDIA \\ *Corresponding author. E-mail: rbinnu@gmail.com
}

Received: January 13, 2017; Revised received: April 16, 2017; Accepted: September 15, 2017

\begin{abstract}
Study on the soil nutrient status and crop productivity under continuous use of inorganic fertilizers and amendments in an acid Alfisol after 36 years (1972-73 to 2008-09) was carried out at Palampur, HP. Results showed that application of Recommended Dose of Fertilizer (120:60:40 kg/ha to maize and 120:60:30 kg/ha to wheat) with $10 \mathrm{t}$ farmyard manure/ha applied once a year for 36 years resulted in 786 and 515 per cent increase in maize and wheat yields, respectively over control. Soil acidity rose from 5.8 to 4.58 with the application of fertilizers over 36 years. Conjoint use of FYM with 100 per cent NPK substantially improved the Organic Carbon status by $4.95 \mathrm{~g} / \mathrm{kg}$ as well as available $\mathrm{P}, \mathrm{K}$ and $\mathrm{S}$ by $154.1,14.5$ and $12.5 \mathrm{~kg} / \mathrm{ha}$, respectively in soil over its initial values, thereby indicating significant contribution towards sustaining the soil health. On the other hand, there was a drastic decline in the available $\mathrm{N}$ status of soil in all the treatments as compared to the initial value. The various root parameters viz., root mass density $\left(4.08 \mathrm{~kg} \mathrm{~m}^{-3}\right)$, root volume density $\left(10.84 \mathrm{~m}^{3} \mathrm{~m}^{-3} \times 10^{-3}\right)$, root length density $\left(2.60 \mathrm{~m} \mathrm{~m}^{-3} \mathrm{x}\right.$ $\left.10^{-4}\right)$, root surface area $\left(204.12 \mathrm{~m}^{2} \times 10^{-4}\right)$ and root cation exchange capacity $\left(8.37 \mathrm{c} \mathrm{mol}\left(\mathrm{p}^{+}\right) \mathrm{kg}^{-1}\right)$ were found to be highest in the plots with the application of $100 \%$ NPK + FYM. Thus, balanced use of fertilizers continuously either alone or in combination with amendments is necessary for sustaining soil fertility and productivity of crops.
\end{abstract}

Keywords: Crop productivity, Long-term fertilization, Maize-wheat, Root dynamics, Soil nutrient status

\section{INTRODUCTION}

Maize-wheat is the most important cropping system of Himachal Pradesh. The acreage under maize and wheat in the state is 295 and 365 thousand hectares, respectively A bulk of the food production in the state comes from these two crops forming about 85 per cent of the total share with productivity of 1671 and $2233 \mathrm{~kg} / \mathrm{ha}$ for wheat and maize, respectively (Anonymous, 201516). Therefore, raising the viability of this important cropping sequence holds key to the transformation of agricultural scenario in Himachal Pradesh. A considerable number of studies, concerning long-term fertility trials, pointed out that soil organic material applications increased the organic carbon stock and, therefore, increased the cation exchange capacity. This effect was due to the high negative charge of organic matter. This is important for retaining nutrients and making them available to plants (Diacono and Montemurro, 2010). These experiments can be used for precise monitoring of changes in soil fertility and productivity and can be of paramount help in solving the complex problems related to soil fertility managements such reduced the energy level of soil humus and enhanced its condensation degree, aromaticity and aging function. Though chemical fertilizers increase crop production; their overuse has hardened the soil, decreased fertility, strengthened pesticides, polluted air and water, and released greenhouse gases, thereby bringing hazards to human health and environment as well. In continuous cropping, use of imbalanced nutrients ( $\mathrm{N}$ or NP alone) through inorganic fertilizers without organic manures and amendments cannot sustain the desired level of crop production. Integration of inorganic fertilizers with organic manures will not only sustain crop production but also will be effective in improving soil health and enhancing the nutrient use efficiency (Thakur et al., 2011). Further, integrated use of organic and inorganic sources of nutrients can improve the root growth facilitating efficient utilization of stored soil moisture and nutrients (Bandopadhyay et al., 2003). Sustained efforts are needed to improve and maintain this most important natural resource base - the soil through judicious integration of mineral fertilizers, 
organic and green manures, crop residues and biofertilizers so that it nourishes intensive cropping without being irreversibly damaged in the process (Swarup 2010). Keeping this in view, the present investigation was undertaken to study the long-term effect of fertilizers and amendments on the various root parameters of wheat crop. There is little information on the effect of continuous cropping and fertilization on crop productivity and root dynamics in an acid Alfisol, hence present study was undertaken.

\section{MATERIALS AND METHODS}

The present study was a part of an ongoing All India Coordinated Research Project on Long-term Fertilizer Experiment with maize-wheat cropping sequence which was initiated during 1972 at Department of Soil Science, CSK Himachal Pradesh Krishi Vishvavidyalaya. The experimental farm is situated at $32^{\circ} 6^{\prime} \mathrm{N}$ latitude and $76^{\circ} 3^{\prime} \mathrm{E}$ longitude at an altitude of about 1290 $\mathrm{m}$ above mean sea level and is characterized as mid hill sub-humid zone of Himachal Pradesh. The climate of the experimental area is characterized as wet temperate with mild summers (March to June) and cool winters (December to February). The total rainfall of about $2713 \mathrm{~mm}$ was received during the crop period with June to September being the wettest months. The soil of the experimental site is illitic, Typic Hapludalfs. Initial properties of the soil are: silty clay loam in texture with clay 24 per cent, silt 47 per cent and sand 29 per cent, $\mathrm{pH} 5.8$, organic carbon $7.9 \mathrm{~g} \mathrm{~kg}^{-1}$, available $\mathrm{N}$ 736, available P 12, available K 194.2 and available S $13.5 \mathrm{~kg} \mathrm{ha}^{-1}$, respectively (Sharma et al., 2002). The experiment comprised of eleven treatments with four replications in a randomized block design. $\mathrm{T}_{1}$ : Control; $\mathrm{T}_{2}: 100 \% \mathrm{~N} ; \mathrm{T}_{3}: 100 \% \mathrm{NP} ; \mathrm{T}_{4}: 100 \% \mathrm{NPK} ; \mathrm{T}_{5}: 100 \%$ NPK + FYM; $\mathrm{T}_{6}: 100 \% \mathrm{NPK}+$ lime; $\mathrm{T}_{7}: 100 \% \mathrm{NPK}+$ $\mathrm{Zn} ; \mathrm{T}_{8}: 100 \% \mathrm{NPK}+\mathrm{HW} ; \mathrm{T}_{9} 100 \%$ NPK (-S); $\mathrm{T}_{10}$ : $150 \%$ NPK; $\mathrm{T}_{11}: 50 \%$ NPK. The $11^{\text {th }}$ treatment $(100 \%$ NPK-S) was introduced in kharif 1981. The 100 per cent NPK dose corresponds to the state level recommendations for the corresponding nutrients and is 120 $\mathrm{kg} / \mathrm{ha} \mathrm{N}, 26 \mathrm{~kg} / \mathrm{ha} \mathrm{P}$ and $33 \mathrm{~kg} / \mathrm{ha} \mathrm{K}$ for maize and 120 $\mathrm{kg} / \mathrm{ha} \mathrm{N}, 26 \mathrm{~kg} / \mathrm{ha} \mathrm{P}$ and $25 \mathrm{~K} \mathrm{~kg} / \mathrm{ha}$ for wheat. The sources of N, P and K were urea, single super phosphate and muriate of potash, respectively. In 100\% NPK (-S), P was applied through di-ammonium phosphate to assess the effect of ' $\mathrm{S}$ ' free high analysis $\mathrm{P}$ fertilizer in crop production. $\mathrm{Zn}$ was applied in $\mathrm{T}_{7}$ as zinc sulphate at the rate of $25 \mathrm{~kg} / \mathrm{ha}$ every year to both the crops. The maize (kharif) and wheat (rabi) crops were sown on $7^{\text {th }}$ June 2008 and $11^{\text {th }}$ November 2008, and harvested on $25^{\text {th }}$ September 2008 and $20^{\text {th }}$ May 2009, respectively Chemical weed control measures were followed in both the crops except in $\mathrm{T}_{8}(100 \%$ NPK + hand weeding), where weeds were removed manually.

After the harvest of the crops at maturity grain and straw yields were recorded separately. Grain yield of maize was standardized at thirteen per cent moisture content and stover yield on oven dry basis, whereas in wheat, yields of both grain and straw were recorded on air-dry basis. The organic carbon was determined by Walkley and Black (1934), available $\mathrm{N}$ by alkaline permanganate method (Subbiah and Asija 1956), available P (Olsen et al., 1954), available K (Black, 1965) and Available S (Chesnin and Yien, 1950).

Root studies were carried out after the harvest of wheat crop. The root samples were taken by core break method (Bohm 1979) to a depth of 0.0-0.30 m and washed with tube well water followed by distilled water to make them free from any soil particles. The root length (RLD) was computed using the modified version of Newman (1966) formula proposed by Marsh (1971) and Tennant (1975):

Root Length (R): 11/14* number of intersections (N) * grid unit

The grid unit was combined with 11/14 factor, which gave a factor of 0.786 for one grid square, root volume (RVD): displacement method, root mass density (RMD): fresh weight of roots was divided with the volume of the sampling core to compute root mass density and root surface area (RSA): Area $\left(\mathrm{cm}^{2}\right)=2$ [volume $\left(\mathrm{cm}^{3}\right) \mathrm{x} \pi \mathrm{x}$ length $\left.(\mathrm{cm})\right]^{1 / 2}$ was determined by displacement method (Mishra and Ahmed 1987) and root CEC (RCEC) was analyzed by the method of Crooke (1964).

\section{RESULTS AND DISCUSSION}

Crop productivity: Continuous application of $100 \mathrm{per}$ cent $\mathrm{N}$ alone through urea for the last thirty-six years declined the yield in 100 per cent $\mathrm{N}\left(\mathrm{T}_{2}\right)$ to $0.0 \mathrm{t} / \mathrm{ha}$ in both the crops (Table 1). Among rest of the treatments, the grain and stover/straw yield of maize and wheat was lowest in control $\left(\mathrm{T}_{1}\right)(1.78$ and $1.46 \mathrm{t} / \mathrm{ha}$, respectively) while highest in 100 per cent NPK + FYM $\left(\mathrm{T}_{5}\right)$ (13.9 and $9.7 \mathrm{t} / \mathrm{ha}$, respectively). These two treatments differed significantly from rest of the treatments except 100 per cent NPK + lime $\left(\mathrm{T}_{6}\right)$ being at par with $\mathrm{T}_{5}$. The plots where $\mathrm{Zn}$ was applied along with 100 per cent NPK $\left(T_{7}\right)$ and in plots where Hand Weeding $\left(T_{8}\right)$ was practiced, yields were found to be at par with 100 per cent NPK alone. The addition of P in combination with $\mathrm{N}$ showed marked increase in maize (365 and 105\% increase) and wheat (377 and 158\% increase) productivity over $\mathrm{N}$ alone and control treatment. However, the continued absence of $\mathrm{K}$ and $\mathrm{S}$ in crop nutrition led to drastic decline in the crop yield (133 and $66.8 \%$ ). The yield of maize and wheat in NP ( $\left.\mathrm{T}_{3}\right)$ and NPK(-S) $\left(\mathrm{T}_{9}\right)$ treated plots was significantly lower than the plots receiving 100 per cent NPK during the last 36 years. Further, the results of correlation coefficients revealed that the both maize and wheat grain and stover/straw yields showed positive and highly significant correlation with soil $\mathrm{pH}(0.436 *$ and $0.454 * *$, respectively $)$ 
Shweta Shambhavi et al. / J. Appl. \& Nat. Sci. 9 (4): 2004 -2012 (2017)

Table 1. Long-term effect of chemical fertilizers and amendments on productivity (tonnes/ha) of maize and wheat.

\begin{tabular}{llcccc}
\hline \multirow{2}{*}{ Treatment } & \multicolumn{3}{c}{ Maize } & \multicolumn{2}{c}{ Wheat } \\
\cline { 2 - 6 } & Control & Grain & Stover & Grain & Straw \\
\hline $\mathrm{T}_{1}$ & $100 \% \mathrm{~N}$ & 0.49 & 1.29 & 0.39 & 1.07 \\
$\mathrm{~T}_{2}$ & $100 \% \mathrm{NP}$ & 0.00 & 0.00 & 0.00 & 0.00 \\
$\mathrm{~T}_{3}$ & $100 \% \mathrm{NPK}$ & 1.09 & 2.56 & 1.10 & 2.67 \\
$\mathrm{~T}_{4}$ & $100 \% \mathrm{NPK}+\mathrm{FYM}$ & 2.73 & 5.78 & 1.93 & 4.36 \\
$\mathrm{~T}_{5}$ & $100 \% \mathrm{NPK}+$ lime & 4.34 & 9.56 & 3.12 & 6.58 \\
$\mathrm{~T}_{6}$ & $100 \% \mathrm{NPK}+\mathrm{Zn}$ & 4.00 & 9.24 & 2.86 & 6.02 \\
$\mathrm{~T}_{7}$ & $100 \% \mathrm{NPK}+\mathrm{HW}$ & 2.46 & 5.82 & 1.85 & 4.27 \\
$\mathrm{~T}_{8}$ & $100 \% \mathrm{NPK}(-\mathrm{S})$ & 2.81 & 6.42 & 2.05 & 4.87 \\
$\mathrm{~T}_{9}$ & $150 \% \mathrm{NPK}$ & 0.91 & 2.18 & 1.33 & 2.73 \\
$\mathrm{~T}_{10}$ & $50 \% \mathrm{NPK}$ & 2.56 & 5.67 & 1.73 & 4.09 \\
$\mathrm{~T}_{11}$ & 1.60 & 3.80 & 1.52 & 3.38 \\
$\mathrm{CD}(\mathrm{p}=0.05)$ & 0.35 & 0.82 & 0.29 & 0.80 \\
\hline
\end{tabular}

Table 2. Correlation coefficients (r) between yield and soil physico-chemical parameters.

\begin{tabular}{lcccc}
\hline & \multicolumn{2}{c}{ Maize } & \multicolumn{2}{c}{ Wheat } \\
\cline { 2 - 5 } & Grain & Stover & Grain & Straw \\
\hline $\mathbf{( 0 . 0}-\mathbf{0 . 2 0} \mathbf{~ m )}$ & & & & $0.426^{*}$ \\
$\mathrm{pH}$ & $0.436^{*}$ & $0.462^{* *}$ & $0.732^{* *}$ & $0.711^{* *}$ \\
$\mathrm{OC}$ & $0.725^{* *}$ & $0.712^{* *}$ & & $0.457^{* *}$ \\
$\mathbf{( 0 . 2 0}-\mathbf{0 . 4 0} \mathbf{~ m )}$ & & & $0.472^{* *}$ & $0.729^{* *}$ \\
\hline $\mathrm{pH}$ & $0.459^{* *}$ & $0.481^{* *}$ & $0.751^{* *}$ & \\
OC & $0.734^{* *}$ & $0.733^{* *}$ & & \\
\hline
\end{tabular}

*Significant at $5 \%$ and ** Significant at $1 \%$ level of significance.

Table 3. Long-term effect of chemical fertilizers and amendments on some chemical parameters of soil after the harvest of maize.

\begin{tabular}{|c|c|c|c|c|c|c|c|}
\hline \multirow{2}{*}{\multicolumn{2}{|c|}{ Treatment }} & \multirow{2}{*}{ pH } & \multirow{2}{*}{$\mathrm{OC}(\mathrm{g} / \mathrm{kg})$} & \multicolumn{4}{|c|}{ Available nutrients (kg/ha) } \\
\hline & & & & $\mathbf{N}$ & $\mathbf{P}$ & $\mathbf{K}$ & $\mathbf{S}$ \\
\hline \multicolumn{8}{|c|}{$(0.0-0.20 \mathrm{~m})$} \\
\hline $\mathrm{T}_{1}$ & Control & 5.57 & 8.67 & 256.1 & 4.7 & 126.6 & 11.6 \\
\hline $\mathrm{T}_{2}$ & $100 \% \mathrm{~N}$ & 4.58 & 9.43 & 297.9 & 8.0 & 153.1 & 13.2 \\
\hline $\mathrm{T}_{3}$ & $100 \% \mathrm{NP}$ & 5.17 & 9.65 & 308.4 & 136.8 & 107.9 & 20.0 \\
\hline $\mathrm{T}_{4}$ & $100 \%$ NPK & 5.28 & 9.68 & 318.8 & 140.0 & 144.8 & 22.8 \\
\hline $\mathrm{T}_{5}$ & $100 \% \mathrm{NPK}+\mathrm{FYM}$ & 5.27 & 12.85 & 334.5 & 166.1 & 208.7 & 26.0 \\
\hline $\mathrm{T}_{6}$ & $100 \% \mathrm{NPK}+$ lime & 6.32 & 10.25 & 303.1 & 134.4 & 133.6 & 25.7 \\
\hline $\mathrm{T}_{7}$ & $100 \% \mathrm{NPK}+\mathrm{Zn}$ & 5.01 & 9.48 & 282.2 & 123.1 & 145.5 & 24.3 \\
\hline $\mathrm{T}_{8}$ & $100 \% \mathrm{NPK}+\mathrm{HW}$ & 5.29 & 10.98 & 313.6 & 96.2 & 144.9 & 23.2 \\
\hline $\mathrm{T}_{9}$ & $100 \%$ NPK(-S) & 5.09 & 9.60 & 303.1 & 115.8 & 155.8 & 14.0 \\
\hline $\mathrm{T}_{10}$ & $150 \% \mathrm{NPK}$ & 4.67 & 9.98 & 324.1 & 220.1 & 174.2 & 26.0 \\
\hline $\mathrm{T}_{11}$ & $50 \% \mathrm{NPK}$ & 5.37 & 9.58 & 287.4 & 48.2 & 144.1 & 17.0 \\
\hline \multicolumn{2}{|c|}{ Initial status } & 5.8 & 7.9 & 736 & 12 & 194.2 & 13.5 \\
\hline \multicolumn{2}{|c|}{$\mathrm{CD}(\mathrm{p}=0.05)$} & 0.160 & 0.457 & 21.60 & 10.79 & 15.64 & 1.57 \\
\hline \multicolumn{8}{|c|}{$(0.20-0.40 \mathrm{~m})$} \\
\hline $\mathrm{T}_{1}$ & Control & 5.30 & 5.65 & 214.3 & 2.3 & 110.5 & 6.2 \\
\hline $\mathrm{T}_{2}$ & $100 \% \mathrm{~N}$ & 4.45 & 5.95 & 235.2 & 6.2 & 139.2 & 6.8 \\
\hline $\mathrm{T}_{3}$ & $100 \% \mathrm{NP}$ & 5.09 & 7.30 & 250.9 & 102.8 & 93.7 & 13.8 \\
\hline $\mathrm{T}_{4}$ & $100 \% \mathrm{NPK}$ & 5.13 & 6.27 & 261.3 & 117.6 & 130.8 & 19.4 \\
\hline $\mathrm{T}_{5}$ & $100 \% \mathrm{NPK}+\mathrm{FYM}$ & 5.05 & 10.85 & 287.4 & 123.2 & 194.5 & 20.9 \\
\hline $\mathrm{T}_{6}$ & $100 \% \mathrm{NPK}+$ lime & 6.18 & 8.45 & 250.9 & 97.1 & 122.1 & 20.2 \\
\hline $\mathrm{T}_{7}$ & $100 \% \mathrm{NPK}+\mathrm{Zn}$ & 4.86 & 7.15 & 224.7 & 105.6 & 131.8 & 18.8 \\
\hline $\mathrm{T}_{8}$ & $100 \% \mathrm{NPK}+\mathrm{HW}$ & 5.15 & 9.15 & 277.0 & 73.8 & 130.5 & 17.4 \\
\hline $\mathrm{T}_{9}$ & $100 \%$ NPK(-S) & 4.75 & 7.55 & 256.1 & 80.3 & 141.5 & 7.0 \\
\hline $\mathrm{T}_{10}$ & $150 \% \mathrm{NPK}$ & 4.53 & 7.45 & 261.3 & 188.5 & 155.9 & 20.2 \\
\hline $\mathrm{T}_{11}$ & $50 \%$ NPK & 5.28 & 6.02 & 230.0 & 31.4 & 123.9 & 11.8 \\
\hline \multicolumn{2}{|c|}{$\mathrm{CD}(\mathrm{p}=0.05)$} & 0.169 & 0.642 & 21.29 & 5.20 & 10.64 & 1.41 \\
\hline
\end{tabular}


Shweta Shambhavi et al. / J. Appl. \& Nat. Sci. 9 (4): 2004 -2012 (2017)

Table 4. Long-term effect of fertilizers and amendments on different root parameters of wheat.

\begin{tabular}{|c|c|c|c|c|c|c|}
\hline \multirow{2}{*}{\multicolumn{2}{|c|}{ Treatment }} & \multirow{2}{*}{$\begin{array}{c}\text { Root length density } \\
\mathbf{m ~ m}^{-3} \times \mathbf{1 0}^{-4}\end{array}$} & \multirow{2}{*}{$\begin{array}{c}\begin{array}{c}\text { Root mass } \\
\text { density }\end{array} \\
\text { kg m }^{-3}\end{array}$} & \multirow{2}{*}{$\begin{array}{c}\begin{array}{c}\text { Root volume } \\
\text { density }\end{array} \\
\mathrm{m}^{3} \mathrm{~m}^{-3} \times 10^{-3}\end{array}$} & \multirow{2}{*}{$\begin{array}{c}\begin{array}{c}\text { Root surface } \\
\text { area }\end{array} \\
\mathbf{m}^{2} \times 10^{-4}\end{array}$} & \multirow{2}{*}{$\frac{\text { Root CEC }}{\text { c mol }\left(\mathrm{p}^{+}\right) \mathrm{kg}^{-1}}$} \\
\hline & & & & & & \\
\hline $\mathrm{T}_{1}$ & Control & 0.57 & 0.46 & 0.46 & 19.83 & 3.63 \\
\hline $\mathrm{T}_{2}$ & $100 \% \mathrm{~N}$ & 0.00 & 0.00 & 0.00 & 0.00 & 0.00 \\
\hline $\mathrm{T}_{3}$ & $100 \%$ NP & 0.91 & 0.85 & 1.63 & 46.76 & 5.87 \\
\hline $\mathrm{T}_{4}$ & $100 \%$ NPK & 1.21 & 1.83 & 3.88 & 83.07 & 6.83 \\
\hline $\mathrm{T}_{5}$ & $100 \%$ NPK + FYM & 2.60 & 4.08 & 10.84 & 204.12 & 8.37 \\
\hline $\mathrm{T}_{6}$ & $100 \%$ NPK + lime & 2.42 & 3.68 & 9.11 & 180.50 & 7.07 \\
\hline $\mathrm{T}_{7}$ & $100 \% \mathrm{NPK}+\mathrm{Zn}$ & 1.89 & 1.84 & 3.03 & 91.99 & 4.70 \\
\hline $\mathrm{T}_{8}$ & $100 \%$ NPK + HW & 2.32 & 3.26 & 7.20 & 157.21 & 5.77 \\
\hline $\mathrm{T}_{9}$ & $100 \%$ NPK(-S) & 1.01 & 1.07 & 1.69 & 50.35 & 4.07 \\
\hline & $150 \%$ NPK & 2.02 & 2.46 & 4.00 & 109.33 & 5.17 \\
\hline & $50 \%$ NPK & 1.14 & 1.44 & 1.89 & 56.46 & 4.17 \\
\hline \multicolumn{2}{|c|}{$\mathrm{CD}(\mathrm{p}=0.05)$} & 0.064 & 0.040 & 0.210 & 3.190 & 0.183 \\
\hline
\end{tabular}

and organic carbon status of the soil $\left(0.725^{* *}\right.$ and $0.732 * *$, respectively) at both the depths which showed that the yield was greatly influenced by soil physico-chemical properties (Table 2).

The low yield levels of both the crops over the years in zero fertilized plots are understandable and could be explained due to poor inherent capacity of the soils under study to meet the requirement of crops in respect of the essential nutrients. Application of $\mathrm{N}$ alone over the years had most deleterious effect of imbalanced fertilization on crop productivity resulting in zero yields. A number of workers elsewhere in country (Swarup, 2000; Edmeades, 2003; Diacono and Montemurro, 2010; Sharma et al., 2014; Brar et al., 2015) reported complete degradation of soils in plots treated with nitrogen alone over a period of time and thereby resulting in zero yields. It is ascribed to sharp decline in $\mathrm{pH}$ that triggered the process of land degradation by increasing the concentration of $\mathrm{Al}$ and $\mathrm{Fe}$ ions to toxic levels as reported by Kaushal (2002) under same set of management practices rendering the soil completely unsuitable for crop growth.

Application of $\mathrm{P}$ along with $\mathrm{N}$ considerably increased yield of both the crops compared to the application of $\mathrm{N}$ alone. A better supply of phosphorus has been associated with proliferous root growth resulting in enhanced water and nutrient absorption. Secondly, it is essential for laying out primordia for reproductive organs (Tisdale et al. 1985) and so it affects yield in a positive manner. High $P$ fixing capacity of these soils resulting in less available labile form of $P$ to the crop plants might be responsible for spectacular responses to added $\mathrm{P}$. Furthermore, $\mathrm{P}$ enhances the exchangeable cations $\left(\mathrm{K}^{+}, \mathrm{Ca}^{2+}, \mathrm{Mg}^{2+}\right.$, etc. $)$ and reduces the concentration of toxic elements, thereby affecting crop yield. The yield of both the crops declined in later years due to continuous mining of $\mathrm{K}$ resulting in depletion of its native reserves. Decreases in crop yield in the absence of $\mathrm{K}$ have also been reported by Brar et al. (2015). Potassium is required for activation of enzymes, starch synthesis, nitrogen uptake and protein synthesis. The increase crop yields due to the application of $\mathrm{N}, \mathrm{P}$ and $\mathrm{K}$ in adequate amount is, therefore, understandable and explainable.

Increased crop yield over the years in manual weeding treatment may be due to better physico-chemical properties in this treatment and increased microbiological growth, which helps in better root proliferation and thus, increased crop yields (Kaushal 2006). Application of lime increases the soil $\mathrm{pH}$ and decreases the active forms of $\mathrm{Al}$ and soil acidity, thereby providing favourable conditions for crop growth (Kaushal 2006). Further, decline in crop yield due to application of $\mathrm{Zn}$ over the years might be probably because of the increased level of $\mathrm{Zn}$ as well as P (Table 3 ) in the soils. Besides this, the antagonistic effect of $\mathrm{Zn}$ and $\mathrm{P}$ might have also played a role in reducing the yield of both the crops.

The reasons for increased response to farmyard manure are generally ascribed to the beneficial effects of farmyard manure on soil productivity (Brady and Weil, 2002). The organic manures supply nutrients and complexing agents such as dissolved natural organic carbon, humic acid, fulvic acid, polycyclic aromatic hydrocarbon etc. to soil which maintain balanced supply of nutrients to plants. Insoluble nutrients present in soil are solubilized due to fulvic acid and humic acid liberated from the organic materials (between $\mathrm{pH} 4.5$ to 6.5 ) and become available to plants for their growth. The increased availability of micro nutrients and primary nutrients in addition to granular soil conditions favourable for higher biological activity could have resulted in better crop growth and higher yields (Diacono and Montemurro, 2010).

The application of $\mathrm{N}, \mathrm{P}$ and $\mathrm{K}$ at super-optimal level $(150 \%)$ decreased the productivity probably due to emerging deficiencies of secondary nutrients particularly $\mathrm{Mg}$ in the present soil (Sharma et al. 2002). The source of $\mathrm{P}$ in the present study was single super phosphate (SSP), which contained gypsum. The gypsum added through SSP might have met the $\mathrm{Ca}$ and $\mathrm{S}$ requirements but led to $\mathrm{Mg}$ deficiency as a result of con- 
tinuous cropping and manuring. While, comparatively lower yields in sub-optimal level of NPK (50\%) might be due to less exhaustive effects on native reserves of the soil NPK as compared to optimal treatment and thus, sustained yield at low levels (Sharma et al., 2002).

The use of high analysis fertilizer (DAP) has led to considerable decline in crop yields of both the crops. The DAP in comparison to SSP contains 46 per cent $\mathrm{P}$ but no $\mathrm{S}$ and $\mathrm{Ca}$. Its continuous use has therefore, led to sulphur mining of the soil resulting in drastic reduction in the crop yields.

Soil properties: Soil $p H$ : The results in table 3 indicated that continuous cropping and fertilizer use over the years reduced the soil $\mathrm{pH}$, except the treatment involving use of lime $(100 \% \mathrm{NPK}+$ lime $)$ compared to the initial soil $\mathrm{pH}$ value of 5.8. The continuous use of $\mathrm{N}$ alone $\left(\mathrm{T}_{2}\right)$ had the most acidifying effect with $\mathrm{pH}$ value declining to 4.58 in the thirty-sixth cropping cycle. Increasing NPK level from 50 to 150 per cent also increased the level of acidity. The use of lime in combination with NPK increased the soil $\mathrm{pH}$ to almost neutrality $(\mathrm{pH}$ 6.32). Addition of farmyard manure along with NPK also reduced the soil acidity compared to the use of NPK alone. The acidifying effect of nitrogenous fertilizers in the present study seems to have been brought about by cation-anion imbalance in crop plants. Decline in soil $\mathrm{pH}$ with the application of $\mathrm{N}$ alone could be attributed to acid producing nature of urea as nitrogenous fertilizer which upon nitrification releases $\mathrm{H}^{+}$ions which are potential sources of soil acidity. The application of $\mathrm{P}$ and $\mathrm{K}$ through phosphatic and potassic fertilizers and farmyard manure had a moderating effect on soil reaction, which could be attributed to the decrease in the activity of aluminium ions in the soil solution due to chelation by organic molecules and the formation of alumino-phosphate complexes (Edmeades, 2003).

Soil organic carbon: An overall increase in soil organic carbon was observed under all the treatments as compared to its initial status (from 7.9 to $12.85 \mathrm{~g} / \mathrm{kg}$ ). Application of farmyard manure at the rate of $10 \mathrm{t} / \mathrm{ha}$ to the maize crop for last 36 years increased soil organic carbon content $(12.85 \mathrm{~g} / \mathrm{kg})$ over its initial status by about 68 per cent (Table 3 ). The marked increase in the soil organic matter following incorporation of FYM along with NPK as compared to the rest of the treatments is attributed to resultant enhanced crop productivity and associated greater returns of added organic materials in the form of decaying roots, litter and crop residues over the period of thirty six years and slow rate of organic matter decomposition in wet temperate zone of Western Himalayas (Verma and Sharma, 2007). Further, it might have created environment conducive for formation of humic acid which stimulates the activity of soil microorganisms resulting in an increase in the organic carbon content of the soil
(Bajpai et al. 2006). The major reason for liming acidic Alfisols is to improve crop growth and yields through amelioration of $\mathrm{Al}^{3+}$ and sometimes $\mathrm{Mn}^{2+}$ toxicity and/or alleviation of $\mathrm{Ca}^{2+}$ deficiency (Sharma et al., 2014). This causes a large increase in root and above ground biomass growth and an increase in the carbon returns to the soils in the form of roots and decaying crop residues. These effects might have contributed to an increase in SOC content in NPK + lime treatment.

Available N: The continuous manuring and cropping for thirty six years showed noticeable decline in available $\mathrm{N}$ content of soils in all the treatments (Table 3 ). The initial available $\mathrm{N}$ content in soils was $736 \mathrm{~kg} / \mathrm{ha}$, which declined to $256.1 \mathrm{~kg} / \mathrm{ha}$ in the plots receiving zero fertilization after the harvest of thirty-sixth maize crop (Table 3). The application of 100 per cent $\mathrm{N}\left(\mathrm{T}_{2}\right)$, 100 per cent NP $\left(\mathrm{T}_{3}\right)$ and 100 per cent NPK $\left(\mathrm{T}_{4}\right)$ resulted in soil $\mathrm{N}$ depletion of 59.5, 58.1 and 56.7 per cent, respectively in comparison to its initial content. The use of farmyard manure, lime or zinc along with NPK also resulted in 54.5, 58.8 and 61.7 per cent depletion in the available $\mathrm{N}$ pools as compared to its initial status in 1972. The overall decline in the available $\mathrm{N}$ content of soils after the harvest of thirty-sixth maize crop (2008) may be due to leaching losses of $\mathrm{N}$ under very high rainfall conditions and its application schedule not synchronizing with the crop requirement; might be responsible for mining of these soils with respect to nitrogen. Application of 100 per cent NPK + FYM registered maximum content of available $\mathrm{N}$ which might be due to additional supply of $\mathrm{N}$ through farmyard manure. These results are in agreement with those of Brar et. al. (2015). Lower value of available $\mathrm{N}$ in $T_{1}$ is a result of $\mathrm{N}$ mining with continuous cropping without fertilization over a period of thirty-six years.

Available P: The available P content declined in the control and 100 per cent $\mathrm{N}$ treated plots. These plots showed an average decline of 61.1 and 33.5 per cent, respectively over a period of thirty six years. Long term inclusion of $\mathrm{P}$ fertilizers (the treatments involving use of NP and NPK) raised the available soil $\mathrm{P}$ above its initial level of $12 \mathrm{~kg} /$ ha (Table 2). The application of farmyard manure, lime or zinc along with NPK too increased the available $\mathrm{P}$ as compared to the initial status. The increase in available $\mathrm{P}$ with the application of fertilizers at higher levels and in combination with farmyard manure might be ascribed to the addition of $\mathrm{P}$ at higher rates in $\mathrm{T}_{10}$ and inactivation of iron, aluminum and hydroxyl aluminum ions, responsible for $\mathrm{P}$ fixation by FYM in $T_{5}$ treatment as reported by Verma (2002) in the same experimental set up. Besides, decomposition of organic material accompanied by the release of appreciable quantity of $\mathrm{CO}_{2}$ forms a cover on sesquioxides and thus reduces the $\mathrm{P}$ fixing capacity of the soil.. Lime application in conjunction with NPK also markedly increased the available $\mathrm{P}$ status of the 
soil due to reduction in exchangeable acidity and mineralization of organic phosphates. (Sharma et al., 2002; Edmeades, 2003; Diacono and Montemurro, 2010 and Sharma et al., 2014).

Available K: The exchangeable K declined in almost all the treatments except 100 per cent NPK + FYM as compared to its initial status of $194.2 \mathrm{~kg} / \mathrm{ha}$ at the beginning of the experiment (Table 3 ). The decline in available $\mathrm{K}$ content was maximum in the plots receiving no $\mathrm{K}$ for the last thirty-six years. The treatment involving FYM with 100 per cent NPK, however, maintained the initial $\mathrm{K}$ status of soils. The exclusion of $\mathrm{K}$ in crop nutrition (control, 100 per cent $\mathrm{N}$ and 100 per cent NP) has led to the maximum mining of its native pools over the years. The depletion in native $\mathrm{K}$ pools even at recommended rates of application is due to its more crop removals compared to the additions over a period of thirty-six years (Sharma et al. 2002). Farmyard manure is reported not only to be a direct source of $\mathrm{K}$ but also in minimizing the leaching loss by retaining $\mathrm{K}^{+}$ions on exchange sites and release of $\mathrm{K}$ due to interaction of organic matter with clay (Sudhir et al. 2002). The higher levels of K in 150 per cent NPK treatment are due to higher application rates of $\mathrm{K}$ in this treatment. The comparatively higher content of available $\mathrm{K}$ in 100 per cent NPK (-S) might be due to its lower removals emanating due to its lower yields caused by sulphur deficiency with the use of diammonium phosphate (S-free) as source of $\mathrm{P}$ fertilizer.

Available S: The available S content declined in control and 100 per cent $\mathrm{N}$ treated plots as compared to the initial status of $13.5 \mathrm{~kg} / \mathrm{ha}$ (Table 3 ). The available $\mathrm{S}$ being $14.0 \mathrm{~kg} / \mathrm{ha}$ was almost equal to the initial value in the plots where sulphur free phosphatic fertilizer was used. The rest of the treatments showed significant increase in the available $\mathrm{S}$ content of the soil. The graded doses at the rate of 50,100 and 150 per cent of its recommended level increased the soil available $\mathrm{S}$ content to $17.0,22.8$ and $26.0 \mathrm{~kg} / \mathrm{ha}$ at the end of $36^{\text {th }}$ cropping cycle, respectively. Application of FYM, lime or zinc in combination with the recommended dose of NPK showed an increase of 92.8, 90.1 and 79.8 per cent, respectively over the initial status of $13.5 \mathrm{~kg} / \mathrm{ha}$. The increase in the available sulphur in 100 per cent NPK + FYM $\left(\mathrm{T}_{5}\right)$ and 150 per cent NPK $\left(\mathrm{T}_{10}\right)$ might be due to the addition of single super phosphate (SSP) and farmyard manure which contained about 12 and 0.15 per cent of $S$, respectively. The sulphur content of control, 100 per cent $\mathrm{N}$ and sulphur excluded plots was below critical level which could be due to low organic carbon content in control and 100 per cent $\mathrm{N}$ plots as $\mathrm{S}$ is known to be an integral part of soil organic matter and exclusion of $S$ in 100 per cent NPK (-S) plots.

Overall the available nutrient status of all the nutrients was lower in the sub-surface layer with almost similar trend as that observed in the surface layer. Lower contents in sub-surface layer could be ascribed to the lower organic carbon status recorded in this layer (Table 3).

\section{Root dynamics of wheat}

Root length density (RLD): The data from the table 4 revealed that the highest root length density of $2.60 \mathrm{~m}$ $\mathrm{m}^{-3} \times 10^{-4}$ was observed in the plots receiving FYM once in a cropping cycle in combination of recommended level of NPK for 36 years while the lowest RLD of $0.57 \mathrm{~m} \mathrm{~m}-3 \times 10^{-4}$ was found in control. The plots treated with 100 per cent $\mathrm{N}$ alone on the other hand, did not show any root growth. The use of chemical fertilizers at higher levels $\left(T_{10}\right)$ showed about 67 per cent increase while at lower levels $\left(T_{11}\right)$ showed about 6 per cent decrease in RLD in comparison to the recommended level of NPK $\left(\mathrm{T}_{4}\right)$. The omission of $\mathrm{K}$ $\left(T_{3}\right)$ and $S\left(T_{9}\right)$ in plant nutrition also showed reduced root length density as compared to recommended level of NPK.

Root length density (RLD) is an important parameter to model water and nutrient movement in the vadose zone and to study soil-root-shoot-atmosphere interactions (Roshani et al., 2005). No root growth in 100 per cent $\mathrm{N}$ plots might be due to the severe deficiency of $\mathrm{P}$, low organic matter, high soil strength and poor soil aeration essential for root distribution. Also, leaching losses of $\mathrm{N}$ might have rendered its non-availability for root growth. These results are in agreement with the findings of Bandopadhyay et al. (2003) and Shenggang et al. (2016).

Root mass density (RMD): The highest root mass density $\left(4.08 \mathrm{~kg} \mathrm{~m}^{-3}\right)$ was observed in the plots receiving farm yard manure once in a cropping cycle for 36 years in combination with recommended level of NPK (Table 4). There was practically no growth in the plots treated with 100 per cent $\mathrm{N}$ alone continuously for 36 years. Graded doses of chemical fertilizers had almost synergistic effect on root distribution in wheat crop due to long term fertilization. The FYM, lime and manually weeded plot increased the RMD by 122,101 and 78 per cent, respectively over the plots receiving optimal doses of NPK. RMD in the Zn amended plots was statistically at par with 100 per cent NPK treatment. The RMD decreased by 0.98 and $0.76 \mathrm{~kg} \mathrm{~m}^{-3}$ in the plots where 100 per cent NP (without K) and 100 per cent NPK (without S) was applied, respectively over balanced fertilized plots. This increase in root mass weight may be due to more absorption of nutrients via an increase in root surface area (Alpa, 2012).

Root mass density (RMD) increased with the increased $\mathrm{N}$ application in wheat. This may be attributed to better $\mathrm{N}$ nutrition and availability of applied $\mathrm{N}$. The RMD increased significantly with the application of phosphorus which may be due to increase in number as well as length of root hairs. Higher RMD in the plots receiving FYM along with inorganic fertilizers followed by 
the lime treated plots maybe attributed to the efficient utilization of nutrients by the crop in presence of OM resulting in more proliferation of roots (Rajput et al., 1984; Cadisch et al. 1993; Bandopadhyay et al. (2003). Root volume density (RVD): Root volume of wheat (rabi, 2008-09) at the harvest was comparatively higher in the plots receiving zero-fertilization in comparison to the plots receiving 100 per cent $\mathrm{N}$ alone for a period of 36 years. The highest root volume density $\left(10.84 \mathrm{~m}^{3} \mathrm{~m}^{-3} \times 10^{-3}\right)$ was recorded in the 100 per cent NPK + FYM treated plots. RVD increased with the increasing level of chemical fertilizers. The increase in the root volume in 50,100 and 150 per cent NPK treatment was observed to be $1.43,3.42$ and $3.54 \mathrm{~m}^{3} \mathrm{~m}^{-3} \mathrm{x}$ $10^{-3}$, respectively over unmanured plots. The use of 100 per cent NPK + lime and 100 per cent NPK + manual weeding increased the root volume by 134.8 and 85.6 per cent over the use of 100 per cent NPK alone. The exclusion of $\mathrm{K}\left(\mathrm{T}_{3}\right)$ and $\left(\mathrm{T}_{9}\right)$ resulted in reduced RVD as compared to balanced fertilized plots $\left(\mathrm{T}_{4}\right)$.

Root extension and proliferation were discernible to greater extent more with the application of FYM in combination with inorganic fertilizers which could be easily explained on the grounds that the soil under FYM treated plots was more porous and well pulverized, so it exhibited low soil resistance to root penetration, thereby upgrading these two parameters. Another possible explanation is that organic matter also helps in maintaining the ideal soil temperature, moisture and aeration essential for proper root distribution due to its high buffering capacity that results in improved root mass as well as root volume densities of the soil (Bandopadhyay et al. (2003). Profuse growth of secondary roots as well as root hairs by the addition of organic amendments (FYM) might be another important reason for the upgradation of root volume compared to rest of the treatments. The increasing levels of NPK to 150 per cent showed synergistic effect on root distribution and hence root volume.

Root surface area (RSA): A perusal of data in table 4 indicated that the root surface area of the wheat (rabi, 2008-09) after the harvest varied from $19.83 \mathrm{~m}^{2} \times 10^{-4}$ to $204.12 \mathrm{~m}^{2} \times 10^{-4}$ in control and FYM treated plots, respectively. Both these treatments were significantly different from rest of the treatments. Application of lime $\left(\mathrm{T}_{6}\right), \mathrm{Zn}\left(\mathrm{T}_{7}\right)$ and $\mathrm{HW}\left(\mathrm{T}_{8}\right)$ along with recommended doses of chemical fertilizers increased RSA by $97.43,8.92$ and $74.14 \mathrm{~m}^{2} \times 10^{-4}$, respectively over the application of 100 per cent NPK alone $\left(\mathrm{T}_{4}\right)$. Plots treated with 100 per cent NP and 100 per cent NPK (-S) had root surface area of 46.76 and $50.35 \mathrm{~m}^{2} \times 10^{-4}$ and was significantly lower than balanced fertilized plots. Increasing level of chemical fertilizers increased the RSA of wheat significantly. RSA in optimal and superoptimal doses of NPK was 47.1 and 93.6 per cent high- er than sub-optimal treated plots.

The improvement in root growth following FYM application are the tendency of FYM to make the soil porous and pulverized that enhanced the growth and development of roots, it also improve the soil structure thereby, bringing an improvement in surface area (Sharma et al., 2002a).

Root cation exchange capacity (RCEC): The data presented in table 4 revealed that RCEC ranged from 3.63 to $8.37 \mathrm{c} \mathrm{mol}\left(\mathrm{p}^{+}\right) \mathrm{kg}^{-1}$ in control and organically amended plots, respectively. The RCEC in lime amended plots was significantly higher than 100 per cent NPK plots at both 5 and 1\% level of significance. Application of Zn and HW treatments along with 100 per cent NPK reduced the RCEC by 2.13 and $1.06 \mathrm{c}$ mol $\left(\mathrm{p}^{+}\right) \mathrm{kg}^{-1}$ over 100 per cent NPK alone. However, continuous cropping in the 100 per cent $\mathrm{N}$ alone treated plots resulted in extreme limitations of rooting depth, thereby reducing the capacity for exchangeable bases in roots of wheat crop to zero level. Among the graded doses of chemical fertilizers, both superoptimal and sub-optimal doses decreased the root CEC over optimal treatment. The treatments where $\mathrm{K}\left(\mathrm{T}_{3}\right)$ and $\mathrm{S}\left(\mathrm{T}_{9}\right)$ were omitted from plant nutrition led to the reduction of RCEC by 14.1 and 40.4 per cent over balanced fertilized plots.

Higher RCEC in FYM amended plots could be attributed to the fact that organic matter helps in making the soil porous and pulverized which ensures better root development thereby, increasing the root CEC (Bandopadhyay et al. (2003), Shenggang et al., (2016). The increase in root CEC due to liming could be attributed to its effect on soil properties that become more favorable for growth and development of roots resulting in an increased root CEC Hourigan et al. (1961), Sharma et al. (1990) and Yanga et al. (2004).

\section{Conclusion}

The long-term impact of the chemical fertilizers and amendments on the various root parameters viz., root mass density, root volume density, root length density, root surface area and root cation exchange capacity was found positive under organically amended plots $(100 \%$ NPK + FYM) followed by lime treatment due to availability of ideal soil environment essential for their growth. The application of 100 per cent $\mathrm{N}$ had led to the complete deterioration of soil structure, thereby, reduced or negligible root growth in such plots.

From the present study, it is concluded that better and sustainable agricultural practices are needed to bring sustainability in agriculture. Excessive use of chemical fertilizers has long lasting deleterious effects on the soil properties thereby degrading soil health. Thus, conjoint use of fertilizers and amendments will certainly reduce the use of chemical inputs and will give a sustainable growth to agricultural production. 


\section{REFERENCES}

Alpa, Neetu, Tanwar, A., Aggarwal, A. and Gupta, K.K. (2012). Impact of endomycorrhizal fungi and other bioinoculants on growth enhancement of Glycine max (L.) Merrill. Journal of Applied and Natural Science, 4 (1): $111-116$

Anonymous. (2015-16). Statistical Outline of Himachal Pradesh, Directorate of Economics and Statistics, Himachal Pradesh, Shimla

Bajpai, R.K., Chitale, S., Upadhyay, S.K. and Urkurkar, J.S. (2006). Long-term studies on soil physico-chemical properties and productivity of rice-wheat system as influenced by integrated nutrient management in inceptisols of Chhatisgarh. Journal of the Indian Society of Soil Science, 54(1): 24-29

Bandopadhyay, K.K., Misra, A.K., Ghosh, P.K., Hati, K.M. and Mandal, K.O. (2003). Effect of integrated use of farmyard manure and inorganic fertilizers on soil water dynamics, root growth, crop yield and water expense efficiency of rainfed soybean in a vertisol. Journal of Agricultural Physics, 3(1-2): 95-100

Black, C.A. (1965). Methods of soil analysis. Part II. Chemical and mineralogical properties. American society of Agronomy, Madison, Wisconsin, USA

Bohm, W. (1979). Methods of studying root systems. Ecological studies: Analysis and synthesis. 33: 125-139

Brady, N.C. and Weil, R.R. (2002). The Nature and Properties of Soils. Thirteenth edition. Pearson Education (Singapore) Pte. Ltd., Indian Branch. New Delhi

Brar, B.S., Singh, J., Singh, G. and Kaur, G. (2015). Effects of Long Term Application of Inorganic and Organic Fertilizers on Soil Organic Carbon and Physical Properties in Maize-Wheat Rotation. Agronomy, 5: 220-238

Cadisch, G., Ferreira, E., Urguiaga, S., Giller, K.E. and Boddey, R.M. (1993). Nitrogen turn over in a red Latosol: Effect of added carbon on the incorporation of ${ }^{15} \mathrm{~N}$ into soil organic matter. In: Mulongoy $\mathrm{K}$ and Merck R (Eds.). Soil organic matter dynamics and sustainability to tropical agriculture. Wiley-Sayce Co-publication. Leuven, Belgium. p 209-214

Chesnin, L. and Yien, C.H. (1950). Turbidimetric determination of sulphur. Soil Science Society of America Proceedings, 15: 134-136

Crooke, W.M. (1964). The measurement of the cation exchange capacity of plant roots. Plant and Soil, 21:43-49

Diacono, M. and Montemurro, F. (2010). Long-term effects of organic amendments on soil fertility. A review. Agronomy for Sustainable Development, Springer Verlag/EDP Sciences/INRA, 30 (2): 401-422

Edmeades, C. Douglas. (2003). The long term effects of manures and fertilizers on soil productivity and quality: a review. Nutrient Cycling in Agroecosystems, 66:165180

Hourigan, W.R., Franklin, R.E., McLean, E.O. and Bhumbla, D.R. (1961). Growth and calcium uptake by plants as affected by rate and depth of liming. Soil Science Society of America Proceedings, 25: 491-494

Kaushal, V. (2002). Studies on long-term effects of chemical fertilizers and amendments on sustainable use of soil in wet temperate zone of western Himalayas. M Sc Thesis. Department of Soil Science, CSKHPKV, Palampur, India. p 99
Kaushal, V. (2006). Dynamics of organic pools of the nutrients as influenced by long-term use of chemical fertilizers and amendments in an acid Alfisol. Ph D Thesis. Department of Soil Science, CSKHPKV, Palampur, India. $\mathrm{p} 172$

Marsh, B. (1971). Measurement of length in a random arrangement of lines. Journal of Applied Ecology, 8: 265267

Mishra, R.D. and Ahmed, M. (1987) Manual on Irrigation Agronomy. Oxford and IBH Publishing Company Pvt. Ltd. New Delhi. p 319-326

Newman, J. (1966) A method of estimating total root length in a sample. Journal of Applied Ecology, 3: 139-145.

Olsen, S.R., Cole, C.V., Watanabe, F.S. and Dean, L.A. (1954). Estimation of available phosphorus by extraction with sodium carbonate. U.S.D.A. Circ No. 939:1933

Rajput, D.R., Prakash, O. and Singh, T.A. (1984). Movement and fertilizer use efficiency of nitrogen in wheat as affected by crop residues. Bulletin of Indian Society of Soil Science, 13:268-276

Roshani, G.A., Narayanaswamy, G. and Datta, S.C. (2005). Effect of potassium on root length density of wheat at different stages of growth. Journal of the Indian Society of Soil Science, 53: 217-221

Sharma, P.K., Sankhayan, N., Bhardwaj, S.K. and Dixit, S.P. (2002a). Studies on root characteristics and biomass productivity of wheat (Aradhana) in phosphorus, farmyard manure and mulch amended mountain acidic lands of Western Himalayas, India. 17 ${ }^{\text {th }}$ WCSS, 14-21 August, 2002, Thailand

Sharma, P.K., Verma, T.S. and Gupta, J.P. (1990) Ameliorating effects of phosphorus, lime and animal manure on wheat yield and root cation exchange capacity in degraded alfisols of North West Himalayas. Fertilizer Research, 23: 7-13

Sharma, S.P., Subehia, S.K. and Sharma, P.K. (2002). Longterm effects of chemical fertilizers on soil quality, crop productivity and sustainability. Research Bulletin CSK Himachal Pradesh Krishi Vishvavidyalaya. p 33

Sharma, U., Paliyal, S.S., Sharma, S.P. and Sharma, G D. (2014). Effects of Continuous Use of Chemical Fertilizers and Manure on Soil Fertility and Productivity of Maize-Wheat under Rainfed Conditions of the Western Himalayas. Communications in Soil Science and Plant Analysis, 45 (20): 2647-2659

Shenggang, P., Haidong, L., Zhaowen, M., Bob, P., Meiyang, D., Hua, T., Shuijin H. and Xiangru, T. (2016). Effects of Nitrogen and Shading on Root Morphologies, Nutrient Accumulation, and Photosynthetic Parameters in Different Rice Genotypes. Scientific Reports6:32148, DOI: $10.1038 /$ srep 32148

Subbiah, B.V. and Asija, G.L. (1956). A rapid procedure for the determination of available nitrogen in soils. Current Science, 25: 259-260

Sudhir, K., Srikanth, K. and Jayaprakash, S.M. (2002). Sustained crop production under long term fertilizer use in red soil in India. $17^{\text {th }}$ WCSS, 14-21 August 2002, Thailand. 108: 1-10

Swarup, A. (2000). Long-term fertilizer experiments to study changes in soil quality, crop productivity and sustainability. Indian Institute of Soil Sciences, Bhopal

Swarup, A. (2010). Integrated plant nutrient supply and man- 
agement strategies for enhancing soil quality, input use efficiency and crop productivity. Journal of the Indian Society of Soil Science, 58: 25-31

Tennant, D. (1975) A test of modified line intersect method of estimating root length. Journal of Ecology. 63: 9951001

Thakur, R., Sawarkar, S.D., Vaishya, U.K. and Muneshwar, Singh. (2001). Impact of continuous use of inorganic fertilizers and organic manure on soil properties and productivity under soybean-wheat intensive cropping of a vertisol. Journal of the Indian Society of Soil Science, 59(1): 74-81

Tisdale, S.L., Nelson, W.L. and Beaton, J.D. (1985). Soil fertility and fertilizers. Macmillan Publishing Company, New York (USA)

Verma, S and Sharma, P.K. (2007). Effect of long-term manuring and fertilizers on carbon pools, soil structure, and sustainability under different cropping systems in wet-temperate zone of northwest Himalayas. Biol Fertility Soils, 44: 235-24

Verma, S. (2002). Studies on long-term effects of chemical fertilizers and amendments on phosphorus dynamics and its budgeting in wet temperate zone soils of western Himalayas. M Sc Thesis. Department of Soil Science, CSKHPKV, Palampur, India. p 139

Walkley, A. and Black, I.A. (1934). An examination of the Degtjareff (wet acid) method for determining soil organic matter and a proposed modification of the chromic acid titration method. Soil Science, 37: $29-38$

Yanga, C., Yang, L., Yanga, Y. and Ouyang, Z. (2004). Rice root growth and nutrient uptake as influenced by organic manure in continuously and alternately flooded paddy soils. Agricultural Water Management, 70: 67-81 